\title{
Bilevel-Bilateral Sacral Erector Spinae Plane Block for Chronic Pain Management: A Case Report and Short Literature Review
}

\section{Kronik Ağrı Tedavisinde Bilevel Bilateral Sakral Erektör Spina Plan Bloğu: Olgu sunumu ve Literatürün Kısa Gözden Geçirilmesi}

Alper Kilicaslan ${ }^{1}$,

Esra Goger ${ }^{1}$,

Feride Karakus ${ }^{1}$

Ruhiye Reisli ${ }^{1}$,

${ }^{1}$ Department of Anaesthesiology and

Reanimation, Meram Faculty of Medicine,

Necmettin Erbakan University, Konya, Turkey

Geliş Tarihi/Received: 06 January 2020

Kabul Tarihi/Accepted: 05 February 2020

Öz

Son yılların popüler rejyonel anestezi tekniklerinden biri olan erektor spina plan bloğu (ESPB), ilk olarak üst torasik nöropatik ağrı için kullanılmıştır. Daha sonra birçok farklı endikasyonda, farklı seviyelerden (alt torasik ve lomber) hem akut hem kronik ağrı tedavisinde, kullanılmıștır. Sınırlı deneyimimiz, bilevel biletaral uygulanan sakral ESPB'nun, perianal kronik intermittan (aralıklı) ağrının tedavisinde kolay ve etkili bir teknik olduğunu göstermektedir. Bununla birlikte, uygulama noktası, lokal anestezik volümü, duyusal blokaj alanı gibi araştırılması gereken birçok konu mevcuttur. Klinik araştırmaların yetersizliği nedeniyle, bu inceleme şu anda sakral ESPB blok etkinliğinin kanıtını ve rutin kullanımını destekleyememektedir. Sakral ESPB bloğunun etkinliği ve etki mekanizmasını açıklığa kavuşturmak için anatomik radyolojik ve klinik çalışmalara intiyaç vardır.

Address correspondence to: Alper Kilicaslan, Department of Anaesthesiology and Reanimation, Meram Faculty of Medicine, Necmettin Erbakan University, Konya, Turkey e-mail: dralperkilicaslan@gmail.com

\section{ORCID}

Alper Kilicaslan

https://orcid.org/0000-0002-2570-5854 Esra Goger

https://orcid.org/0000-0002-3237-8695 Feride Karakus

https://orcid.org/0000-0002-3237-8695

Ruhiye Reisli

https://orcid.org/0000-0002-1616-5497

\begin{abstract}
Erector spinae plane block (ESPB), one of the popular regional anesthesia techniques in recent years, has first been used for upper thoracic neuropathic pain. Later, it has been used in many different indications for both acute and chronic pain treatment at different lower thoracic and lumbar levels. Our limited experience demonstrates that bilevel bilateral sacral ESPB is an easy and effective method in the treatment of perianal chronic intermittent pain. However, many issues, such as the application site, the volume of local anesthetics and the sensory blockade, still remain being investigated. Due to the lack of clinical research, our review is currently unable to support the evidence and routine use of sacral ESPB. We consider that anatomical radiological and clinical studies are needed to elucidate the efficacy and mechanism of action of sacral ESPB.
\end{abstract}

Key words: Sacrum, erector spinae plane block, chronic pain management, ultrasonography, local anesthesia

\section{INTRODUCTION}

Erector spinae plane block (ESPB), one of the popular regional anesthesia techniques in recent years, has first been used for upper thoracic neuropathic pain (1). Later, it has been used in many different indications for both acute and chronic pain treatment at different lower thoracic and lumbar levels (2). Only recently, various cases in which ESPB was administered due to acute pain at the sacral level have been reported (3-8).

The treatment of end-stage cancer pain is challenging, and when adverse effects arising from especially the use of opioids develop, they usually require interventional approaches. In limited number of case reports related to the use of ESPB due to cancer pain, ESPB has been stated to provide sufficient and continuous analgesia (9-11). To our knowledge, there is no previous report in which sacral ESPB has been used due to chronic cancer pain. Considering the effectiveness of ESPB in chronic pain at upper levels, we have hypothesized that ESPB performed at sacral level would provide effective analgesia in chronic anorectal pain.

\section{CASE}

A written informed consent was obtained from 
the patient for the procedure and the publication of data. A 62-year-old, $70 \mathrm{~kg}$ male patient was admitted to the department of algology with the complaint of intermittent severe pain in the perianal and gluteal region (S2-S5 dermatomes). The patient had undergone anorectal surgery due to rectal cancer (adenocarcinoma) 12 months ago; however, he reported that the pain continued intermittently and was exacerbated during the last two days. So, the patient was evaluated as the numerical rating scale (NRS) of $8-9 / 10$, and the history revealed ejection fraction (EF) $<30 \%$, atrial fibrilation $(A F)$ and the use of anticoagulant. We primarily scheduled to perform bilevel-bilateral sacral ESPB for achieving an immediate acute pain relief. After confirming that the case did not have a coagulation disorder, the patient was placed into the prone position in the pain intervention room, and administered with $1 \mathrm{mg}$ bolus of midazolam and $50 \mu \mathrm{g}$ fentanyl prior to the block performance.

After the block site and ultrasound (USG) probe were sterilized, a linear transducer (10-18 MHz, Esaote My Lab 30, Genoa, Italy) was centered on the L5 vertebra spinous process in the midline. In order to determine the intended level, the transducer was shifted towards the caudal, and the second median crest was imaged. Then, the transducer was laterally moved $3-4 \mathrm{~cm}$, and the intermediate crest (IC) was detected in the parasagittal plane. A 21-gauge, 100$\mathrm{mm}$ block needle (Pajunk, Geisingen, Germany) was inserted in the plane until it was contacted with the bone from the cranial to caudal. While a half of local anesthesia mixture $(25 \mathrm{~mL}$ of $0.25 \%$ bupivacaine and $4 \mathrm{mg}$ of dexamethasone) was administered into the interfascial plane deep to multifidus muscle and erector spinae aponeurosis at the S2-S3 level. We noticed the cranio-caudal spread and that the muscle was elevated above the bone. The needle was then withdrawn and re-directed towards the caudal. The remaining half of the local anesthesia mixture was injected into the same interfascial plane at the S4S5 level (Fig. 1). The same procedure was performed for the opposite side with the same volume, and no complications were observed. A total of $50 \mathrm{~mL}$ of local anesthesia mixture was used for bilevel-bilateral sacral ESPB administered with two injection points. Twenty minutes after the injection, the NRS score was seen to decrease to $2 / 10$. The assessment at 12nd hour revealed a sensory blockage (pinprick) between the L5-S4 dermatomes, and the NRS was still 2/10. At the end of 24th hour, the NRS score was

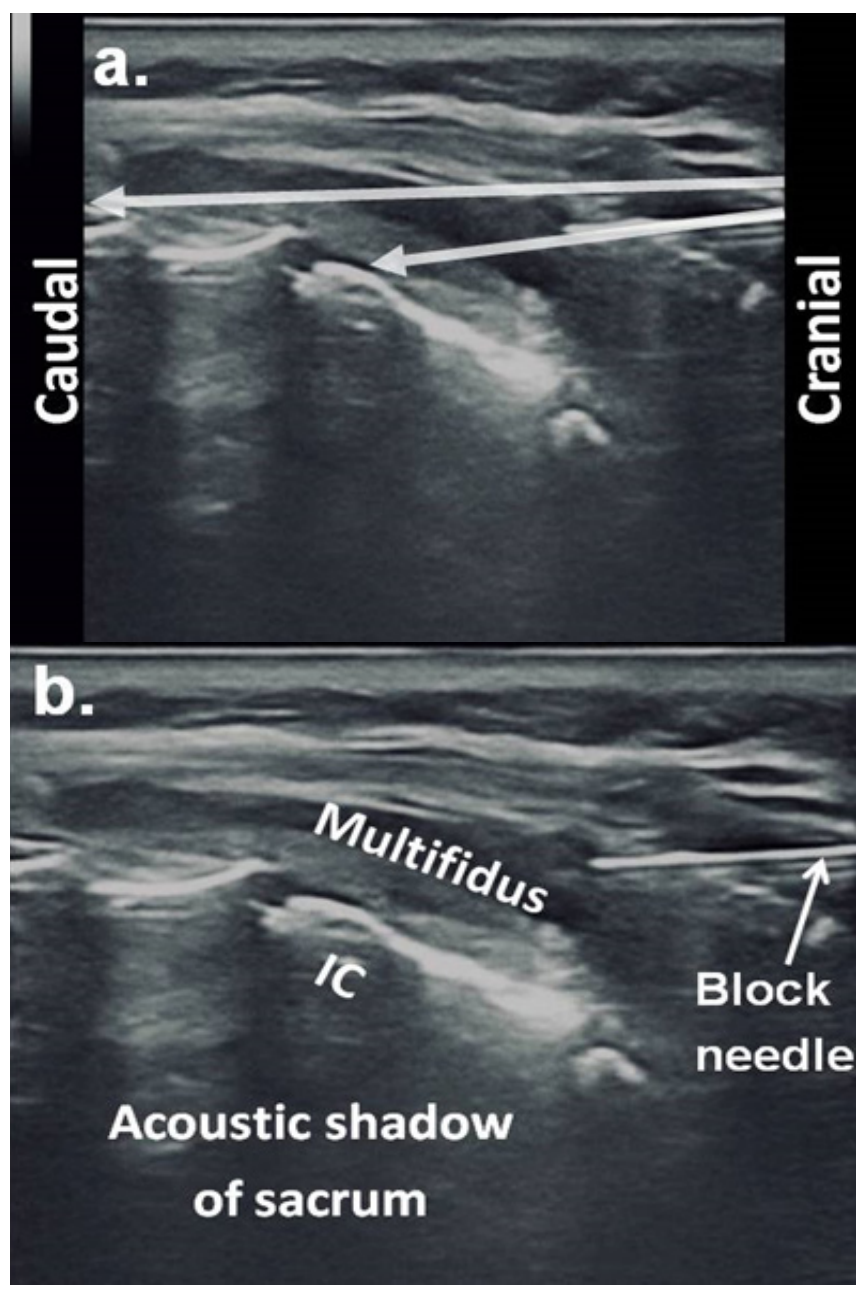

Figure 1. Demonstration (a) and sonoanatomy (b) of sacral erector spinae plane block using the paramedian sagittal approach. Bilevel approach (white arrows) is used to inject local anesthetic deep to the multifidus muscle and erector spinae aponeurosis, IC: intermediate crest.

3-4/10, and the patient needed no rescue analgesics or other opioids. The patient was discharged with oral pregabalin $75 \mathrm{mg}(2 \times 1)$ and tramadol $100 \mathrm{mg}$ tablets.

\section{DISCUSSION}

Our limited experience demonstrates that bilevel sacral ESPB is an easy and effective method in the treatment of perianal chronic intermittent pain. Our case had chronic complex pain following anorectal surgery due to rectal cancer. The treatment of endstage cancer pain is challenging due to the side effects of opioids and its nature in a way to require interventional approaches. It has been reported 
that persistent pain may develop at a rate of 1.5$3.5 \%$ after the transanal rectal resection (12). The underlying cause is primarily taken into consideration in terms of the treatment of chronic anorectal pain; unfortunately, there is no consensus concerning the treatment process (13). Based on literature, such invasive procedures as caudal, epidural blocks, sacral nerve stimulation and local anesthetic infiltration have been performed in addition to the medical treatment $(14,15)$. In performing sacral ESPB, local anesthetic is administered to the facial plane under the erector spinae aponeurosis and multifidus muscle, as in the thoracolumbar region; however, it is a quite different block due to anatomical differences. Erector spinae muscles overlay on the transverse processes of the lumbar vertebrae and continue over the sacral laminae. The field of application and sonographic images are more synonymous with the retrolaminar region. Therefore, Hamilton stated that the terms "sacral retrolaminar block" or "sacral multifidus plane block" could be applied to this technique (16).

Although quite limited number of case reports related to sacral ESPB have been published, no randomized controlled trials are currently available. However, sacral ESP blocks have been performed at different levels to the cases from different age groups. Therefore, we decided to review clinical data based

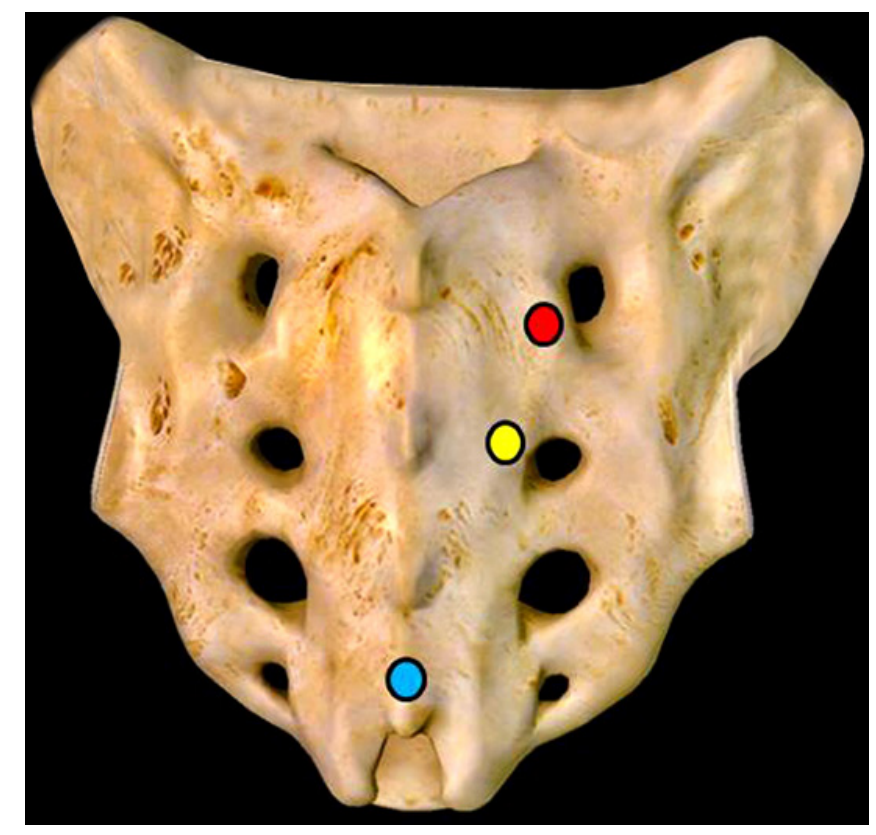

Figure 2. Red $(4,7)$, yellow $(3)$ and blue dots $(5,6)$ show the basic illustration of defined injection points of the sacral erector spinae plane block. on literature in order to grasp the general features of sacral ESPB, and so searched and reviewed on PubMed, "Google Scholar" and "Web of Science" by using the key words of "sacral erector spinae plane block" between January 2017 and December 2019.

The following information was extracted from the five case reports we obtained: (a) the indications for the block, (b) the level for which the block was performed and anatomical localization, (c) the type, dose and concentration of local anesthetics, (e) the type of the block (single shot or catheter placement), (f) the side effects, ( $g$ ) adverse events, and (i) the results. The data obtained from the studies are presented in Table 1, and no adverse events or side effects were reported in any case reports. The single shot technique was used in all case reports. Three different injection sites have been identified for sacral ESPB in various case reports published so far (Fig. 2). In the study by Tulgar et al., it was reported that a sensory blockage was obtained in L5 and the first three posterior branches of sacral nerves as the result of ESPB performed at the second sacral level. On the other hand, these authors advocated that the injected agents did not spread to the anterior branches of the sacral nerve or the sacral plexus (3). In later reports, however, different results were reported to be obtained. In another study by Aksu and Gurkan, it was reported that a local anesthetic at a dose of $1 \mathrm{~mL} / \mathrm{kg}$ ( $8 \mathrm{~mL}$ of $0.25 \%$ bupivacaine) was administered with a single injection from the midline at the level of $4 \mathrm{rd}$ median sacral crest to a 6-month infant. In the same study, the authors also reported that there was no need unexpectedly for additional analgesics during the first 24 hours, and claimed the epidural spread (5).

In our study, however, we obtained clinical evidence regarding the blockade of the dorsal and ventral branches of the spinal nerves after bilevelbilateral sacral ESPB we performed with relatively higher volumes. In both the present case report and our previously published reports $(7,8)$, we observed the spread of local anesthesic agent to cranial and caudal, to the lumbar region under the erector spinae muscle, as similar to the finding reported by Piraccini et al. (4). Thus, we consider the injected material may have reached the anterior branches of the spinal nerves. However, the mechanism of possible epidural diffusion of the enjectate administered from the midline and S4 level still remains unclear. If different mechanisms of action were detected through future studies, the naming or definition could 
Table 1. Information extracted from case reports related to sacral erector spinae plane block

\begin{tabular}{|c|c|c|c|c|c|}
\hline $\begin{array}{l}\text { Authors } \\
\text { (Reference) }\end{array}$ & Indication & Patients' age & $\begin{array}{l}\text { Sacral level and } \\
\text { localisation of block }\end{array}$ & $\begin{array}{l}\text { Volume, type of local } \\
\text { aesthetic and additives }\end{array}$ & Comments \\
\hline Tulgar $\mathrm{S}^{3}$ & $\begin{array}{l}\text { Pilonidal sinus } \\
\text { surgery, PPM }\end{array}$ & 28 years-M & $\begin{array}{l}\text { S2, Intermediate } \\
\text { sacral crest, bilateral }\end{array}$ & $\begin{array}{l}10 \mathrm{~mL} \text { Bupivacaine } 0.5 \% \text {, } \\
5 \mathrm{~mL} \text { Lidocaine } 2 \%, 5 \mathrm{~mL} \\
\text { Normal saline for each } \\
\text { side (totally } 40 \mathrm{~mL} \text { ) }\end{array}$ & $\begin{array}{r}\text { NRS } 0 / 10 \\
\text { after } 40 \text { min } \\
\text { of block NRS } \\
<3 / 10 \text { in first } \\
13 \text { hours }\end{array}$ \\
\hline Piraccini $E^{4}$ & $\begin{array}{l}\text { Acute } L 5 \\
\text { radicular pain }\end{array}$ & 67 years-M & $\begin{array}{l}\text { S1, Intermediate } \\
\text { sacral crest }\end{array}$ & $\begin{array}{l}\text { Ropivacaine } 30 \mathrm{mg} \\
\text { and Triamcinolone } \\
40 \mathrm{mg} \text { (totally } 15 \mathrm{~mL} \text { ) }\end{array}$ & $\begin{array}{c}\text { NRS } 0 / 10 \text { after } \\
20 \text { min of block } \\
\text { NRS }<4 / 10 \text { after } \\
7 \text { days }\end{array}$ \\
\hline Aksu $C^{5}$ & $\begin{array}{l}\text { Hypospadias } \\
\text { repair, PPM }\end{array}$ & 6 months & $\begin{array}{l}\text { S4, Median } \\
\text { sacral crest }\end{array}$ & $\begin{array}{l}8 \mathrm{~mL} \text { of } 0.25 \% \\
\text { Bupivacaine } \\
(1 \mathrm{~mL} / \mathrm{kg})\end{array}$ & $\begin{array}{l}\text { LACC } 0 \text { or } 1 \\
\text { first } 24 \text { hours }\end{array}$ \\
\hline Oksuz $\mathrm{G}^{6}$ & $\begin{array}{l}\text { Anoplasty } \\
\text { surgery, PPM }\end{array}$ & 7 months & $\begin{array}{l}\text { S4, Median } \\
\text { sacral crest }\end{array}$ & $\begin{array}{l}9 \mathrm{ml} 0.25 \% \\
\text { Bupivacaine }(1 \mathrm{~mL} / \mathrm{kg})\end{array}$ & $\begin{array}{l}\text { FLACC } 0 \text { in } \\
\text { first } 24 \text { hours }\end{array}$ \\
\hline Kilicaslan $A^{7}$ & $\begin{array}{l}\text { Pelvic and } \\
\text { sacral fracture } \\
\text { surgery, PPM }\end{array}$ & $\begin{array}{l}\text { Case } 1: \\
69 \text { years-M } \\
\text { Case 2: } \\
29 \text { years-M }\end{array}$ & $\begin{array}{l}\text { S1, Intermediate } \\
\text { sacral crest, } \\
\text { bilateral }\end{array}$ & $\begin{array}{l}10 \mathrm{~mL} \text { Bupivacaine } \\
0.5 \%, 5 \mathrm{~mL} \text { Lidocaine } \\
2 \% \text { and } 5 \mathrm{~mL} \\
\text { Normal saline for } \\
\text { each side (totally } 40 \mathrm{~mL} \text { ) }\end{array}$ & $\begin{array}{l}\text { Case } 1 \text { : VAS } \\
<3 / 10 \text { in first } \\
14 \text { hours } \\
\text { Case } 2 \text { : VAS } \\
1 / 10 \text { in first } \\
12 \text { hours } \\
\text { VAS } 4 / 10 \\
\text { at } 24 \mathrm{~h} .\end{array}$ \\
\hline
\end{tabular}

FLACC: Face, leg, activity, cry and consolability; M: Male; NRS: Numeric rating scale; PPM: Postoperative pain management; VAS: Visual analog scale

be changed, and novel classifications, such as upper, lower or lateral sacral ESPB may be termed. Also, the differences related to the anatomy of pediatric population and the permeability of the tissues may be other issues to be considered. The main limitation of our study is that previous reports are mostly case reports, meaning low-grade evidence. There are no randomized controlled trials in literature.

Sacral ESPB seems to be an easy technique because of the absence of large vessel and nerve structures at the facial plane, and because the defined target points are superficial. However, it is obvious that further studies are needed to elucidate the side effects and unexpected events.

\section{CONCLUSION}

As a result, sacral ESPB may be a promising method to relieve the acute postoperative and chronic pain in light of previous case reports. However, many issues need to be clarified, such as the anatomical nomenclature, the application site, the volume of local anesthetics and the sensory blockade arae. Due to the lack of clinical research, our review is currently unable to support the evidence and routine use of sacral ESPB. We consider that anatomical radiological and clinical studies are needed to elucidate the efficacy and mechanism of action of sacral ESPB.

Conflict of interest: Authors declare that there is no conflict of interest between the authors of the article.

Financial conflict of interest: Authors declare that they did not receive any financial support in this study.

Address correspondence to: Alper Kilicaslan, Necmettin Erbakan University, Meram Faculty of Medicine, Department of Anesthesiology and Reanimation 42080, Meram, Konya, Turkey

Mobile number: +900505 3780376

E-mail:dralperkilicaslan@gmail.com

\section{REFERENCES}

1. Forero M, Adhikary SD, Lopez $\mathrm{H}$, et al. The erector spinae plane block: A novel analgesic technique in thoracic neuropathic pain. Reg Anesth Pain Med 2016:41(5):621-7.

2. De Cassai A, Bonvicini D, Correale C, et al. Erector spinae plane block: A systematic qualitative review. Minerva Anestesiol 2019:85(3):308-19.

3. Tulgar S, Senturk O, Thomas DT, et al. A new technique for sensory blockage of posterior branches of sacral nerves: Ultrasound guided sacral erector spinae plane block. J Clin Anesth $2019: 57: 129-30$.

4. Piraccini E, Antioco M, Maitan S. Ultrasound guided sacral erector spinae plane block: A useful tool for radicular pain treatment.J Clin Anesth 2020:59:11-2. 
5. Aksu C, Gürkan Y. Sacral erector spinae plane block with longitudinal midline approach: Could it be the new era for pediatric postoperative analgesia?J Clin Anesth 2020:59:389.

6. Öksüz G, Arslan M, Bilal B, et al. Ultrasound guided sacral erector spinae block for postoperative analgesia in pediatric anoplasty surgeries.J Clin Anesth 2020:60:88.

7. Kilicaslan A, Aydin A, Kekec AF, et al. Sacral erector spinae plane block provides effective postoperative analgesia for pelvic and sacral fracture surgery. J Clin Anesth 2019:4:109674.

8. Kilicaslan A, Uyel Y. Novel lumbosacral approach for erector spinae plane block (LS-ESPB) in hip surgery. J Clin Anesth 2020:60:83-4.

9. Ramos J, Peng P, Forero, M. Long-term continuous erector spinae plane block for palliative pain control in a patient with pleural mesothelioma. Canadian Journal of Anesthesia 2018:65(7):852-3.

10. Tayfun A, Balaban O, Demir L. Ultrasound guided erector spinae plane block for pain management in pancreas cancer: A case report.Agri 2019:31(4):218-9.

11. Aydın T, Balaban $O$, Acar $A$. Ultrasound guided continuous erector spinae plane block for pain management in pulmonary malignancy. J Clin Anesth 2018:46:63-4.
12. Kunitake $H$, Poylin V. Complications following anorectal surgery. Clinics in colon and rectal surgery 2016:29(01):1421.

13. Gürel $A$, Unal $N$, Elevli $M$, et al. Epidural morphine for postoperative pain relief in anorectal surgery. Anesthesia and analgesia 1986:65(5):499-502.

14. Siddiqui ZI, Denman WT, Schumann R, et al. Local anesthetic infiltration versus caudal epidural block for anorectal surgery: A randomized controlled trial. J Clin Anesth 2007:19(4):26973.

15. Martellucci J, Naldini G, Del Popolo G, et al. Sacral nerve modulation in the treatment of chronic pain after pelvic surgery. Colorectal Dis 2012:14(4):502-7.

16. Hamilton DL. The erector spinae plane block: Time for clarity over anatomical nomenclature. J Clin Anesth 2020:62;109699. 